\title{
Production of Activated Carbon Electrodes from Sago Waste and its application for an Electrochemical Double-Layer Capacitor
}

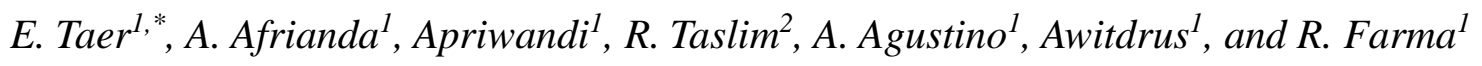 \\ ${ }^{1}$ Department of Physics, University of Riau, 28293 Simpang Baru, Riau, Indonesia \\ ${ }^{2}$ Departement of Industrial Engineering, Islamic State University of Sultan Syarif Kasim, 28293 \\ Simpang Baru, Riau, Indonesia. \\ "E-mail: erman_taer@yahoo.com
}

doi: $10.20964 / 2018.11 .27$

Received: 8 June 2018 / Accepted: 27 August 2018 / Published: 1 October 2018

\begin{abstract}
Research on the utilization of sago waste as an activated carbon electrode for an electrochemical double-layer capacitor (EDLC) has been successfully performed. An important part of the EDLC is the highly porous activated carbon electrode that is prepared without the addition of adhesive materials with an optimum physical activation time. The sago waste-based activated carbon was prepared without adhesive materials with different physical activation times of 0.5, 1.0, 1.5, 2.0 and 2.5 hours. The effect of the physical activation time is discussed in terms of the physical and electrochemical properties of the carbon electrodes. The evaluated physical properties of the electrode include the density, surface morphology, chemical element content, degree of crystallinity and surface area. The electrochemical properties of the supercapacitor cells were studied for specific capacitances on a twoelectrode system using the cyclic voltammetry method. The optimum specific capacitance of the sample electrode was $132 \mathrm{~F} \mathrm{~g}^{-1}$, which was achieved with an activation time of 2.5 hours.
\end{abstract}

Keywords: sago waste; physical activation time; supercapacitor

\section{$\underline{\text { FULL TEXT }}$}

(C) 2018 The Authors. Published by ESG (www.electrochemsci.org). This article is an open access article distributed under the terms and conditions of the Creative Commons Attribution license (http://creativecommons.org/licenses/by/4.0/). 